\title{
Türk Tahvillerinin CDS Primlerini Etkileyen İssel Faktörlerin Analizi
}

Murat AKKAYA 1

Makale Gönderim Tarihi: 21.11.2016

Makale Kabul Tarihi: 28.03.2016

\section{Öz}

Kredi Temerrüt Swapları (CDS) finansal piyasalarda en yaygın kullanılan kredi türevlerinden bir tanesidir. Türk tahvillerinin CDS primleri ve primleri etkileyen faktörler üzerine sayılı çalıșma bulunmaktadır. Çalıșmanın amacı, küresel kriz öncesinden günümüze kadar olan küresel kriz döneminde Türk tahvillerinin kredi risk primini etkileyen içsel değișkenlerin belirlenmesidir. Çalıșma Ocak 2008- Mart 2016 dönemini kapsamaktadır. Türkiye 5 Vadeli ABD Tahvil CDS priminin aylık değișimlerinde Borsa İstanbul getiri endeksi ve altın fiyatı değișkenlerinin dıșsal olduğunu ve bu bağımsız değișkenlerin gecikmeli değerlerinin bağımlı değișkenin nedeni olduğunu göstermektedir faktörler

Anahtar Kelimeler: Türk tahvilleri, CDS, VAR analizi, İçsel

\section{Analysis of Internal Factors Affecting CDS Premiums of} Turkish Treasuries

\section{Abstract}

Credit Default Swaps (CDS) is one of the most widely used credit derivatives in financial markets. In finance literature, there are few studies on factors affecting CDS premiums of Turkish bonds. The aim of the study is to determine the internal variables

1 Yrd. Doç. Dr., İstanbul Arel Üniversitesi, IïBF, Uluslararası Ticaret Finans Bölümü (Ingilizce) 
affecting Turkish bonds' credit risk premiums in the period of the global crisis. The study covers January 2008 to March 2016 period. Istanbul Stock Exchange return index and the price of gold is exogenous variables on Turkey USD 5 Term Bond CDS and lagged values of these variables are the cause of the dependent variable.

Keywords: Turkish bonds, CDS, VAR, Endegenous variables

\section{Giriș}

Finansal piyasalarda yașanan önemli risklerden biri tanesi de kredi riskidir. Kredi riskinden korunma amacıyla kredi türevleri olarak adlandırılan yeni mali varlıklar geliștirilmiș ve kredi risklerinin yönetilmesi amaçlanmıștır. Kredi Temerrüt Swapları (Credit Default Swaps - CDS) finansal piyasalarda en yaygın kullanılan kredi türevlerinden bir tanesidir.

Kredi Temerrüt Swapları bir sigorta ișlemi olarak düșünülmektedir. Bu ișlemde alacaklı, borçlunun borcunu ödememesi veya ödeyememesi riskinden kendisini korumak için veya alacağını garanti etmek üzere bir sigorta ișlemi yaptırmaktadır. Bu sigorta ișleminde riski üstlenen tarafa ödenecek bir bedel bulunmaktadır ki bu da CDS puanına (CDS Spread) göre belirlenen primdir.

Kredi temerrüt swapı ile temerrüde düșme, iflas, kredi notunun düșmesi vb. belirgin kredi olayları sonucunda finansal varlığın uğrayacağı potansiyel kayıplar taraflar arasında transfer edilmektedir. Referans varlı̆ı̆ı veya yükümlülüğün sahibi olan taraf koruma satın almaktadır. Böylece söz konusu varlığı bilançodan çıkarmadan kredi riskinin transfer edilmesi sağlanmaktadır (Karabıyık ve Anba, 2008).

Kredi Temerrüt Swaplarının yapısı ve ișleyiși Șekil 1'de görülmektedir. 


\section{Șekil 1.}

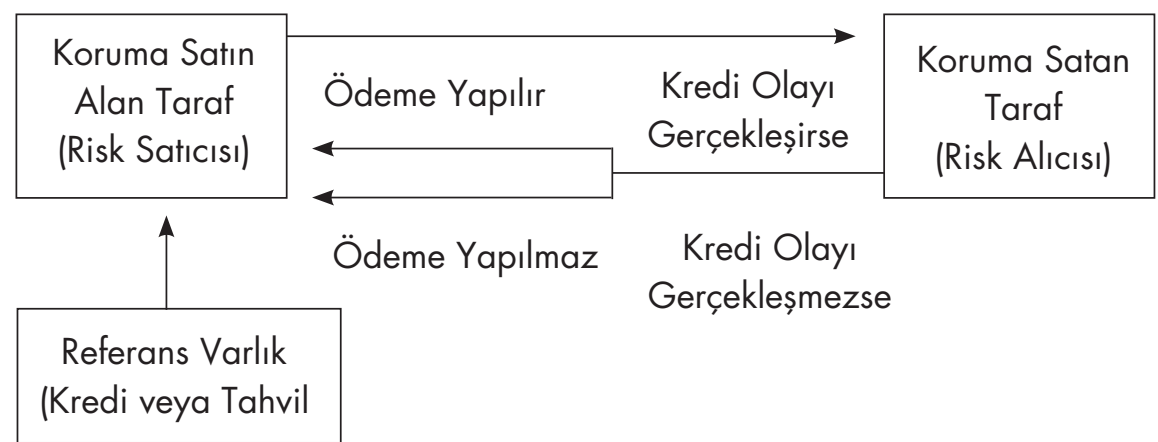

Kaynak: Choudhry, 2006: 2.

Kredi Temerrüt Swapı (CDS) kavramı 1995 yılında JP Morgan tarafından finans dünyasına kazandırılmıșıır. CDS, piyasada olușabilecek riskleri takip aracı olarak da kullanılmaktadır. Yukarıdaki șekilde referans varlığa sahip borçlunun riski yükseldikçe, CDS puanları da yükselmektedir. Bașka bir ifade ile CDS puanlarının yükselmesi, borçlunun ve içerisinde bulunduğu ekonominin riskinin yükseldiğini belirtmektedir.

Türk tahvillerinin CDS'leri, 2003 yılından itibaren yoğun olarak uluslararası piyasalarda izlenmeye bașlanmıștır. Türk tahvillerinin CDS primleri ve primleri etkileyen faktörler üzerine sayılı çalıșma bulunmaktadır. Bu çalıșmalarda genellikle Borsa İstanbul endeksleri ve temel makroekonomik değișkenler kullanılmıștır.

Çalıșmanın amacı küresel kriz döneminde Türk tahvillerinin kredi risk primini etkileyen içsel değișkenlerin belirlenmesidir. Araștırma kapsamında küresel kriz öncesinden, günümüze kadar olan dönem incelenmiștir. Çalıșma Ocak 2008- Mart 2016 dönemini kapsamaktadır. Uzun dönemli çift yönlü ilișkiye bakılmıș ve ilișkinin yönü araștırılmıștır. Bu çalıșmada 5 yıl vadeli ABD Doları Türk tahvillerin CDS primleri ve içsel faktörler dikkate alınmıștır.

\section{Literatür Araștırması}

Finans yazınındaki Kredi Temerrüt Swapları çalıșmalarını Duffie (1999) bașlatmıștır. Duffie risksiz değișken faizli bir tahvili 
ile riskli değișken faizli bir tahvil CDS arbitrajının zor olabileceğini belirtmektedir.

Hull ve White (2000), Hull ve White (2001), Skinner ve Townend (2002)'in çalıșmaları diğer araștırmalara öncülük etmiștir. Kredi risk primi modelleri iki grup altında incelenmiștir: yapısal modeller Black ve Scholes (1973) ve Merton (1974) ve indirgenmiș formdaki modeller (Litterman ve Iben (1991) ve Jarrow ve Turnbull (1995). Yapısal modellerde, firmanın varlıklarındaki bozulmayı kredi riski olarak sınıflandırmaktadır ve varlıkları temerrüt limitinin alında olan ișletmelerin kısa zaman diliminde temerrütle karșılașacağı varsayılmaktadır. İndirgenmiș formdaki modellere göre temerrüt olușma zamanı, rassal bir duruș noktasıdır. Gruber, (A. S. Kunt ve O. Taș 2008).

Ming (1998) çalıșmasında, Türkiye ve gelișmekte olan ülkelerin tahvilleri ile Amerikan Hazine tahvilleri arasındaki getiri farkını araștırmıștır. Yapılan çalıșmada Borç/GSYiH, iç-dıș borç çevirme rasyolarının istatistiki açıdan anlamlı olduğu görülmüștür. Bu değișkenlerin bir ülkenin borcunu geri ödeyebilme kabiliyetini en iyi șekilde açıkladığı belirtilmiștir.

Gruber ve diğerleri (2001) devlet tahvilleri ile șirket tahvilleri arasındaki faiz farkını açıklamaya çalıșmıșlardır. Faiz farklarının 3 unsura bağlı olduğunu bulmușlardır: beklenen temerrütten kayıplar, vergiler ve sistematik risk için talep edilen prim.

Chan-Lau (2003) CDS farklarına uyan alternatif risk ölçüsü araștırmıștır. Çalıșmasında Brezilya, Bulgaristan, Kolombiya, Rusya ve Venezuela'da CDS ve tahvil primleri arasında ilișkiye bakmıștır. Chan-Lau çalıșmasında bu değișkenler arasında anlamlı ve güçlü ilișki bulmuștur.

A. S. Kunt, O. Tass (2008), 19/10/2000 - 17/01/2008 döneminde Türkiye'nin CDS sözleșmelerinin prim tutarları ve opsiyon fiyatlamasında etkili olan beș temel değișkenden risksiz faiz oranı, referans varlığın getirisi ve referans varlığın getirisinin volatilitesi üzerine çalıșmıșlardır. Çalıșmada 1, 2, 3, 4, 5, 7 ve 10 yıl vadeli CDS primleri kullanılmıș ve değișkenler arasında uzun dönemli ilișkinin mevcut olduğu görülmüștür. 
Ersan ve Günay (2009) Türkiye'de Adalet ve Kalkınma partisine karșı açılan kapatma davasının, CDS 'swap spreadleri' üzerinde etkisi VAR (Vektör Oto Regresif) yöntemi ile araștırmıșlar, ancak anlamlı bir ilișki bulamamıșlardır. Ayrıca, Türkiye CDS spreadleri ile Dow Jones Endeksi ve 2030 vadeli Türkiye eurobond faizi arasında istatiski anlamlı bir ișki gözlemlenmiștir.

Zhang, Yau ve Fung (2010) CDS primleri ile döviz piyasasının ilișkisini bakmıșlardır. Granger nedensellik testi kullanarak 2007-2008 kriz döneminde Japon Yeni, Euro, İngiliz Poundu ve Avustralya doları ve CDS primlerini araștırmıșlardır. Çalıșma sonucunda CDS endeks farklarının para ticareti (carry-trade) bilgisi sağladığı görülmüștür.

Pollege ve Posch (2013), Avrupa borç krizini araștırmıșlardır. CDS primi tahvil porfföyü arasındaki bazın varlık yöneticileri ve ișlemciler için değerli sinyalleri verip vermediğini çalıșmıșlardır. Mayıs 2000-Aralık 2010 döneminde 13 Avrupa ülkesini incelenmiștir. Çalıșma sonucunda CDS Pazar likiditesinin öncü güç olduğu, CDS pazarının risklere tahvil pazarından daha hızlı bir șekilde tepki verdiği yönünde bulgular elde edilmiștir.

Koy (2014), çalıșmasında CDS (Kredi Temerrüt Swapı) ve Euro-tahvil primleri arasındaki ilișkiyi incelemiștir. Ocak 2009-Kasım 2012 döneminde iki değișkeni karșılaștırmıștır. Çalıșmada 8 Avrupa ülkesinin CDS primleri ile Euro-tahvil primleri arasındaki nedensellik ilișkisine bakılmıș ve Granger nedensellik testi kullanımıștır. Çalıșma sonucunda Fransa ve İtalya CDS primlerinin, tahvil primlerini etkilediği görülmüștür.

Kargı (2014) 2005-2013 döneminde eș bütünleșme ve Granger nedensellik testleri kullanarak Türk CDS dağılımları, faiz oranları ve büyüme arasındaki ilișkiyi incelemiș ve faiz oranlarının CDS dağılımlarını etkileyen önemli bir unsur olduğunu gözlemlemiștir. Ayrıca CDS dağılımları, faiz oranı ve büyüme arasında uzun dönemli anlamlı ilișki saptanmıștır.

Hancı (2014), 2008- 2012 döneminde Türkiye CDS dağılımları ile BiST-100 getirileri arasındaki ilișkiyi GARCH yöntemi ile modellemiș ve CDS baz puanı ile BIST-100 getirileri arasında 
negatif yönlü bir ilișki bulunmuștur. Ayrıca değișkenler arasındaki oynaklık çok yüksek çıkmıș, șokların dirençli olduğu ve ortalamaya geri dönüșlerin zaman aldığı görülmüștür.

\section{Veriler ve Yöntem}

Araștırmada, Türkiye 5 Vadeli ABD Doları Tahvil CDS primi (CDS), 1 gr altın fiyatı (GOLD), bankacılık sektörü yurtiçi kredi hacmi (BSYKH), cari açık (CA), Bloomberg Tüketici Güven Endeksi (BGE), dıș ticaret dengesi (DTD), doğrudan yatırımlar (DY), Borsa İstanbul getiri endeksi (BIST-G), İç borç stoku (IBS), İhracatın İthalatı karșilama oranı (IHRITHKO), toplam ihracat (IHR), toplam ithalat (ITH), imalat sanayi kapasite kullanım oranı (ISKKO), ișsizlik oranı (IO), kısa vadeli dıș borç stoku (KVBS), Net Hata Noksan (NHN), net uluslararası rezervler (NUR), Portföy yatırımları (PY), TÜFE bazIı Reel Kur Endeksi (REELKUR), sanayi üretim endeksi (SUE), T.C. Merkez Bankası Bileșik Reel Kesim Güven Endeksi (TCMBRKGE), T.C. Merkez Bankası Bileșik Öncü Gösterge (TCMBBOG), TUIK Tüketici Güven Endeksi (TUIKTGE), tüketici fiyatları fiyat endeksi (TFFE), ABD yıllık döviz Faizi (USDFAIZ), ABD Doları kuru (USDKUR), yurtdıșı yerleșiklerin hisse senedi stoku (YYHSS), Türk Euro tahvillerinin risk primleri (Türkiye 2030 Vadeli Eurobond Risk Primi- EMBITR) ve Chicago Opsiyon Borsası Oynaklık Endeksi (VIX) verilerine ilișkin aylık değerler incelemeye dahil edilmiștir.

Araștırma Ocak 2008 - Mart 2016 dönemini kapsamaktadır ve toplam 99 adet aylık gözlem bulunmaktadır. Türkiye 5 Vadeli ABD Tahvil CDS primlerinin aylık değișimlerinin ortalaması 1,5164, medyanı 1.88 ve standart sapması 15,2497 olarak belirlenmiștir.

İlgili dönemdeki Türkiye 5 Vadeli ABD Doları Tahvil CDS primleri grafiksel olarak Șekil 2'de gösterilmiștir. 


\section{Șekil 2. Türkiye 5 Vadeli ABD Doları Tahvil CDS primleri}

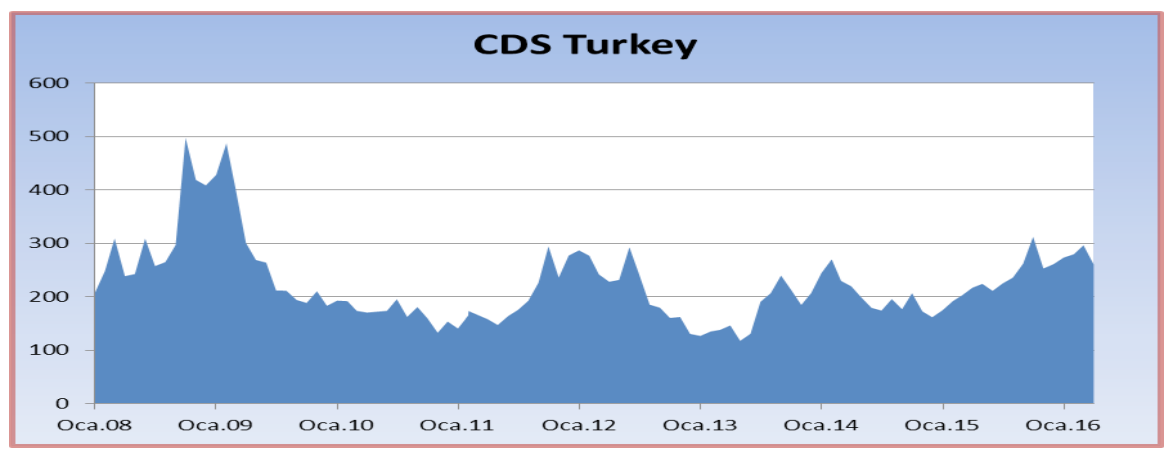

Araștırmada seçilen verilerin aylık oransal değișimleri kullanılmıștır. Bașka bir ifadeyle verilerin bir önceki aya göre değișim oranları kullanılmıștır.

Ocak 2008 - Mart 2016 döneminde, Türkiye 5 Vadeli ABD Doları Tahvil CDS priminin aylık yüzdesel değișimleri Șekil 3’de gösterilmiștir.

\section{Șekil 3. Türkiye 5 Vadeli ABD Tahvil CDS priminin aylık \% değișimleri}

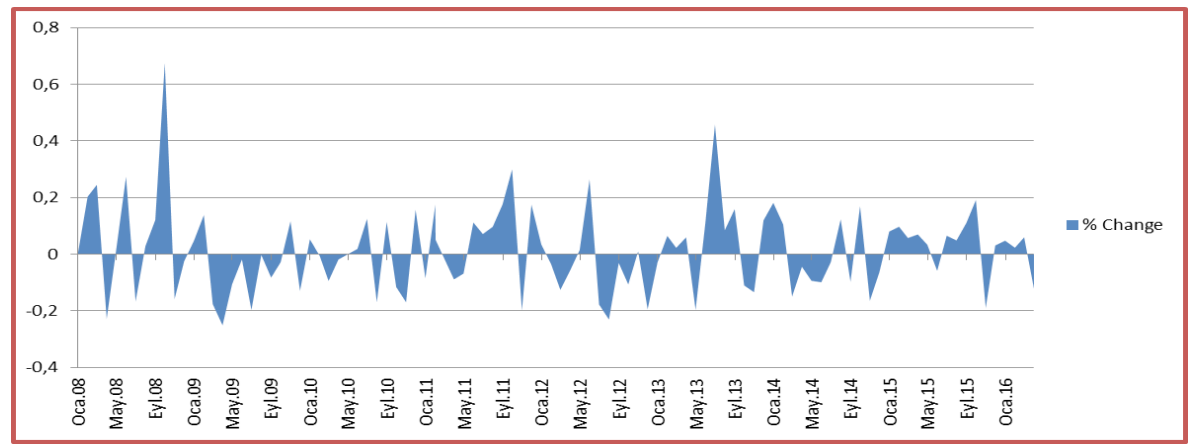

BIST-100 Getiri Endeks verileri² Borsa İstanbul'un internet sitesinden, Bloomberg Tüketici Güven Endeksi verileri³ Bloomberg șirketininin internet sitesinden, TUIK Tüketici Güven Endeksi veri-

2 http://borsaistanbul.com/veriler/verileralt/hisse-senetleri-piyasasi-verileri/piyasaverileri

3 http://www.cnbce.com/cnbc-e-endeksleri/tuketici-guven-endeksi 
leri ${ }^{4}$ Türkiye İstatistik Kurumunun resmi internet sitesinden, diğer değișken verileri T.C. Merkez Bankasının resmi internet sitesinin Elektronik Veri Dağıım Sistemi'nden ${ }^{5}$, Türkiye 5 Vadeli ABD Doları Tahvil CDS primi ve Chicago Opsiyon Borsası Oynaklık (Korku) Endeksi verileri ise Bloomberg firmasının internet sitesinden elde edilmiștir.

Araștırma yöntem itibariyle 2 așamadan olușmaktadır. Birinci așamada; Ocak 2008 - Aralık 2016 döneminde Türkiye 5 Vadeli ABD Doları Tahvil CDS primi ile diğer değișkenler arasındaki ilișki klasik çoklu regresyon analizi ile araștırılmıștır. Bu bölümde amaç, Türkiye'nin 5 Vadeli ABD Doları Tahvil CDS primi ile değișkenler arasındaki ilișkinin belirlenmesidir. Ikinci așamada, Türkiye'nin 5 Vadeli ABD Doları Tahvil CDS primi ile diğer değișkenler arasındaki ilișki VAR analizi ile incelenmiștir. Bu așamada değișkenler arasında göstergelerin gecikmeli etkisini gözlemeyebilmek, nedensellik ilișkisi ve dinamik olarak göstergeler arasındaki etkileșimin boyutunu tespit edebilmek amaçlanmıștır.

\section{Uygulama ve Bulgular}

Finans modellemelerinde ve araștırmalarında zaman serilerinin durağan olması ve birim kök tașımaması gerekmektedir. Zaman serileri analizine uygunluğunun incelenmesi açısından serilerin durağan olup olmadığı, Dickey ve Fuller (1981) tarafından geliștirilen, Augmented Dickey-Fuller (ADF) birim kök testi uygulanarak test edilmiș ve \% 1 anlamlılık düzeyinde bütün serilerin durağan olduğu, ardıșık bağımlılığın olmadığı görülmüștür.

Türkiye 5 Vadeli ABD Doları Tahvil CDS primi ile değișkenler arasındaki korelasyon incelenmiștir. Borsa İstanbul getiri endeksi (BIST-G) ile - 0,6673, Türk Euro tahvillerinin risk primleri (Türkiye 2030 Vadeli Eurobond Risk Primi- EMBITR) ile 0,8836, ABD Dolar kuru (USDKUR) ile 0,7560 ve Chicago Opsiyon Borsası Oynaklık Endeksi (VIX) ile 0,4894 korelasyon saptanmıștır. Diğer değișkenler ile korelasyon oldukça düșüktür.

\footnotetext{
$4 \quad$ http://tuikapp.tuik.gov.tr/tukguvenapp/index.zul

5 http://evds.tcmb.gov.tr/cbt.html
} 
Birinci așamada uygulanan regresyon analizinin katsayıları incelendiğinde; \% 5 düzeyinde Türkiye 5 Vadeli ABD Doları Tahvil CDS primi ile $A B D$ Dolar kuru (USDKUR) ve Türk Euro tahvillerinin risk primleri (Türkiye 2030 Vadeli Eurobond Risk Primi- EMBITR) aylık değișimler arasında istatistiki ve anlamlı bir ilișki bulunmaktadır. Söz konusu regresyon modelinin açıklama gücü (R-squared) 0,8823 , belirginlik katsayısı (Adjusted R-squared), yani modelin açıklama gücü ise 0,8353 olarak belirlenmiștir (Tablo 1).

\section{Tablo 1: Regresyon modelinin sonuçları}

\begin{tabular}{|c|c|c|c|c|}
\hline \multicolumn{3}{|c|}{ Dependent Variable: CDS } & & \\
\hline \multicolumn{3}{|c|}{ Method: Least Squares } & \multirow[b]{4}{*}{ t-Statistic } & \multirow[b]{4}{*}{ Prob. } \\
\hline \multicolumn{3}{|c|}{ Sample: 2008M01 2016M03 } & & \\
\hline \multicolumn{3}{|c|}{ Included observations: 99} & & \\
\hline Variable & Coefficient & Std. Error & & \\
\hline BIST-G & -0.185879 & 0.117670 & -1.579 .661 & 0.1187 \\
\hline BSYKH & 0.544027 & 0.631830 & 0.861034 & 0.3922 \\
\hline BGE & 0.007610 & 0.146249 & 0.052034 & 0.9586 \\
\hline $\mathrm{CA}$ & -0.003075 & 0.006077 & -0.505920 & 0.6145 \\
\hline DY & 0.000915 & 0.001669 & 0.548378 & 0.5852 \\
\hline DTD & 0.022022 & 0.013351 & 1.649 .432 & 0.1035 \\
\hline IBS & -0.428800 & 0.999668 & -0.428942 & 0.6693 \\
\hline GOLD & 0.161132 & 0.201816 & 0.798410 & 0.4273 \\
\hline EMBITR & 0.620230 & 0.077400 & 8.013 .266 & 0.0000 \\
\hline IHR & 2.518 .672 & 1.297 .407 & 1.941 .312 & 0.0562 \\
\hline IHRITHKO & -2.369 .375 & 1.312 .990 & -1.804 .565 & 0.0754 \\
\hline ISKKO & -0.163627 & 0.577401 & -0.283385 & 0.7777 \\
\hline IO & 0.086661 & 0.168751 & 0.513541 & 0.6092 \\
\hline ITH & -2.285 .015 & 1.329 .572 & -1.718 .610 & 0.0901 \\
\hline KVBS & -0.054222 & 0.127980 & -0.423672 & 0.6731 \\
\hline NUR & -0.274626 & 0.314489 & -0.873247 & 0.3855 \\
\hline NHN & $-6.43 \mathrm{E}-05$ & $8.69 \mathrm{E}-05$ & -0.739114 & 0.4623 \\
\hline PY & 0.000326 & 0.000507 & 0.642932 & 0.5224 \\
\hline REELKUR & 0.076866 & 0.480393 & 0.160007 & 0.8733 \\
\hline SUE & -0.056341 & 0.095045 & -0.592784 & 0.5552 \\
\hline TCMBBOG & -2.061 .695 & 2.581 .569 & -0.798621 & 0.4272 \\
\hline TCMBRKGE & 0.508477 & 0.265099 & 1.918 .065 & 0.0592 \\
\hline TFFE & 0.231171 & 1.012 .992 & 0.228207 & 0.8202 \\
\hline TUIKTGE & 0.080747 & 0.256428 & 0.314890 & 0.7538 \\
\hline USDFAIZ & -0.028517 & 0.039726 & -0.717836 & 0.4752 \\
\hline USDKUR & 0.977257 & 0.283906 & 3.442 .180 & 0.0010 \\
\hline VIX & 0.000311 & 0.033613 & 0.009255 & 0.9926 \\
\hline YYHSS & -0.108803 & 0.090104 & -1.207 .528 & 0.2313 \\
\hline $\mathrm{C}$ & 0.065830 & 2.041 .677 & 0.032243 & 0.9744 \\
\hline R-squared & 0.882321 & Mean dep & endent var & 1.516 .364 \\
\hline Adjusted R-squared & 0.835249 & S.D. depe & dent var & 1.524 .970 \\
\hline S.E. of regression & 6.189 .774 & Akaike inf & criterion & 6.722 .908 \\
\hline Sum squared resid & 2.681 .932 & Schwarzc & iterion & 7.483 .095 \\
\hline Log likelihood & -3.037 .840 & Hannan-Q & linn criter. & 7.030 .481 \\
\hline F-statistic & 1.874 .422 & Durbin-W & tson stat & 2.343 .395 \\
\hline Prob(F-statistic) & 0.000000 & & & \\
\hline
\end{tabular}


Regresyon yönteminin varsayımlarının geçerliliği incelenmiștir ve hata terimlerinde ardıșık bağımlılık (serial correlation), değișen varyans (heteroscedasticity) ve çoklu doğrusal bağlantı bulunmamıștır.

İkinci așamada, Türkiye 5 Vadeli ABD Doları Tahvil CDS priminin aylık değișimleri ile diğer değișkenler arasındaki ilișki VAR analizi ile incelenmiștir. VAR modeli içsel ve dıșsal değișken ayrımı yapılmasına gerek olmaksızın değișkenlerin birbirleri ile bağlantılı olan birlikte nasıl hareket ettiklerini gösteren bir denklem sistemidir. VAR analizinde tüm değișkenler aynı anda kendi gecikmeleri ve diğer değișkenlerin gecikmeli değerleri ile açıklanmaktadır.

VAR analizinde önce ideal gecikme uzunluğunun belirlenmesi gerekmektedir.

\section{Tablo 2: VAR Gecikme Uzunluğu tablosu}

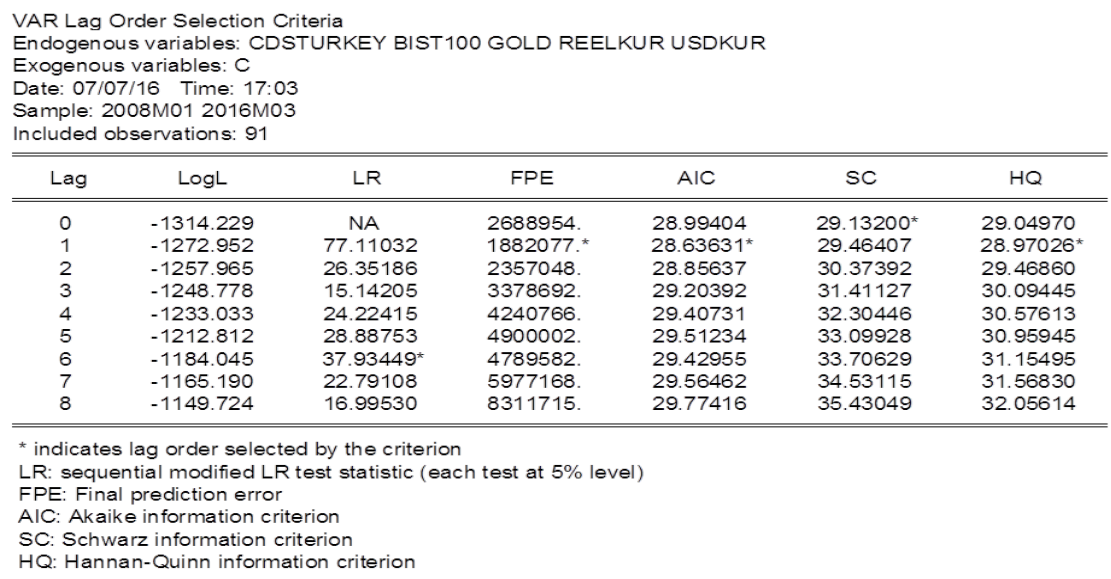

Akaike Bilgi Kriteri (AIC), FPE ve Hannan-Quinn Bilgi kriterleri doğrultusunda en küçük olan 1 (bir) olarak belirlenmiș ve modele dahil edilmiștir (Tablo 2).

Türkiye 5 Vadeli ABD Doları Tahvil CDS priminin aylık değișimler ile diğer değișkenlere VAR Granger nedensellik/Blok Dıșsallık Wald Testi uygulanmıș ve bütünsel olarak anlamlı sonuçlar 
bulunamamıștır. Bunun üzerine değișkenler arasında gruplar olușturulmuș ve ilișkilere bakılmıștır.

Türkiye 5 Vadeli ABD Doları Tahvil CDS priminin aylık değișimler ile Borsa İstanbul getiri endeksi (BIST-G), altın fiyatı (GOLD), TÜFE bazlı Reel Kur Endeksi (REELKUR) ve ABD Dolar kuru (USDKUR) değișkenlerine VAR Granger nedensellik/Blok Dıșsallık Wald Testi uygulanmıștır, Model sonuçları; alıı fiyatı (GOLD) ve Borsa İstanbul getiri endeksi (BIST-G) değișkenlerinin dıșsal olduğunu ve bu bağımsız değișkenlerin gecikmeli değerlerinin bağımlı değișkenin nedeni olduğunu göstermektedir Altın fiyatlarının yurtdıșı piyasa hareketlerine bağlı olması ve Borsa İstanbul üzerinde yabancı yatırımcı hakimiyetinin bulunduğu düșünüldüğünde sonuçlar Türkiye 5 Vadeli ABD Doları Tahvil CDS primleri üzerinde belirlenen içsel faktörlerin etkili olmadığını ve dıșsal kanyaklı faktörlerin etkili olduğunu göstermektedir (Tablo 3).

\section{Tablo 3: VAR Block Exogeneity Wald tablosu}

\begin{tabular}{|c|c|c|}
\hline \multicolumn{3}{|c|}{ VAR Granger Causality/Block Exogeneity } \\
\hline \multicolumn{2}{|c|}{ Bağımlı değişken: CDS } & \multirow[b]{2}{*}{ Prob. } \\
\hline Excluded & Chi-sq & \\
\hline BIST-G & 8.710631 & 0.0128 \\
\hline GOLD & 6.199581 & 0.0451 \\
\hline REELKUR & 1.376331 & 0.5025 \\
\hline USDKUR & 0.467836 & 0.7914 \\
\hline Model & 18.86121 & 0.0156 \\
\hline
\end{tabular}

Türkiye 5 Vadeli ABD Doları Tahvil CDS priminin aylık değișimler ile ìç borç stoku (IBS), imalat sanayi kapasite kullanım oranı (ISKKO), ișsizlik oranı (IO), net uluslararası rezervler (NUR), sanayi üretim endeksi (SUE) ve tüketici fiyatları fiyat endeksi (TFFE), değișkenlerine VAR Granger nedensellik/Blok Dıșsallık Wald Testi uygulanmıștır ve \% 5 düzeyinde model anlamsız çıkmștır (Tablo 4). 


\section{Tablo 4: VAR Block Exogeneity Wald tablosu}

VAR Granger Causality/Block Exogeneity Bağımlı değişken: CDS

\begin{tabular}{|c|c|c|}
\hline Excluded & Chi-sq & Prob. \\
\hline ICBORC & 7.390200 & 0.0248 \\
\hline NUR & 1.801386 & 0.4063 \\
\hline 10 & 0.946510 & 0.6230 \\
\hline ISSIZLIK & 3.144148 & 0.2076 \\
\hline SUE & 1.333119 & 0.5135 \\
\hline TFFE & 3.337101 & 0.1885 \\
\hline Model & 14.94826 & 0.2443 \\
\hline
\end{tabular}

Türkiye 5 Vadeli ABD Doları Tahvil CDS priminin aylık değișimler ile Tüketici Güven Endeksleri arasındaki ilișkiye bakılmıștır. Bloomberg Tüketici Güven Endeksi (BGE), T.C. Merkez Bankası Bileșik Reel Kesim Güven Endeksi (TCMBRKGE) ve TUIK Tüketici Güven Endeksi (TGE) değișkenlerine VAR Granger nedensellik/ Blok Dıșsallık Wald Testi uygulanmıștır ve \% 5 düzeyinde model anlamsız çıkmștır (Tablo 5).

\section{Tablo 5: VAR Block Exogeneity Wald tablosu}

\begin{tabular}{|c|c|c|}
\hline \multicolumn{3}{|c|}{ VAR Granger Causality/Block Exogeneity } \\
\hline \multicolumn{2}{|c|}{ Bağımlı değişken: CDS } & \multirow[b]{2}{*}{ Prob. } \\
\hline Excluded & Chi-sq & \\
\hline BIST-G & 6.887900 & 0.0319 \\
\hline BGE & 0.811281 & 0.6665 \\
\hline TCMBRKGE & 1.661219 & 0.4358 \\
\hline TUIKTGE & 0.733512 & 0.6930 \\
\hline Model & 1.349 .620 & 0.0959 \\
\hline
\end{tabular}

Türkiye 5 Vadeli ABD Doları Tahvil CDS priminin aylık değișimler ile dıș ticaret ișlemleri arasındaki ilișkiye bakılmıștır. Dıș ticaret dengesi (DTD), İhracatın İthalatı karșılama oranı (IHRITH$\mathrm{KO})$, toplam ihracat (IHR), toplam ithalat (ITH), Net Hata Noksan (NHN), net uluslararası rezervler (NUR) değișkenlerine VAR Granger nedensellik/Blok Dıșsallık Wald Testi uygulanmıștır ve \% 5 düzeyinde model anlamsız çıkmștır (Tablo 6). 


\section{Tablo 6: VAR Block Exogeneity Wald tablosu}

\begin{tabular}{|c|c|c|}
\hline \multicolumn{3}{|c|}{ VAR Granger Causality/Block Exogeneity } \\
\hline Excluded & Chi-sq & Prob. \\
\hline IHRACAT & 4.422349 & 0.1096 \\
\hline IHTITHKO & 5.155969 & 0.0759 \\
\hline DTDENGESI & 4.633341 & 0.0986 \\
\hline CISLEMLER & 0.788545 & 0.6742 \\
\hline NHN & 1.139369 & 0.5657 \\
\hline ITHALAT & 3.968743 & 0.1375 \\
\hline NETREZERV & 1.524100 & 0.4667 \\
\hline Model & 2.232 .480 & 0.0722 \\
\hline
\end{tabular}

Değișkenler arasındaki kısa dönemli ilișkiyi görmek amacıyla Granger nedensellik testi uygulanmıștır. Regresyon analizi bağımsız değișkenler ile bağımlı değișkenler arasındaki ilișkiyi göstermektedir. Ancak ilișkinin nedenselliğini göstermemektedir. Bașka bir ifadeyle; değișkenler arasındaki ilișkinin varlı̆̆ı, değișkenler arasında etkinin yönünü veya nedenselliği göstermemektedir. Ancak zaman serileri regresyon analizinde nedensellik durumu çok önemlidir (Gujarati, 1995).

Değișkenler arasındaki Granger nedensellik testi sonuçları Tablo 7'de sunulmuștur. Tablo 7'deki sonuçlara göre Alıın fiyatları, Borsa İstanbul getiri endeksi, İhracatın İthalatı Karșılama Oranı ve T.C. Merkez Bankası Bileșik Öncü Göstergelerden Türkiye 5 Vadeli ABD Doları Tahvil CDS priminin aylık değișimlere doğru ișleyen tek yönlü Granger nedensellik görülmüștür. Ayrıca, Türkiye 5 Vadeli ABD Doları Tahvil CDS priminin aylık değișimlerden Bankacilık Sektörü Yurtiçi Kredi Hacmi, Bloomberg Tüketici Güven Endeksi, İmalat Sanayi Kapasite Kullanım Oranı, Reel Kur ve TUiK Tüketici Güven Endeksine doğru ișleyen tek yönlü Granger nedensellik saptanmıștır. Toplam İthalat ve Türkiye 5 Vadeli ABD Doları Tahvil CDS priminin aylık değișimleri arasında çift yönlü Granger nedensellik saptanmıștır. 
Tablo 7: Granger Nedensellik ilișkisi

\begin{tabular}{|l|r|r|}
\hline \multicolumn{3}{|c|}{ Pairwise Granger Causality Tests } \\
\hline \multicolumn{3}{|c|}{} \\
\hline Null Hypothesis: & F-Statistic & Prob. \\
\hline BISTG - CDSTURKEY & 5,70805 & 0,0046 \\
\hline CDSTURKEY - BISTG & 0,66136 & 0,5186 \\
\hline CDSTURKEY - BSYKH & 6,21134 & 0,0029 \\
\hline BSYKH - CDSTURKEY & 1,40642 & 0,2502 \\
\hline CDSTURKEY - BGE & 7,62151 & 0.0002 \\
\hline BGE - CDSTURKEY & 0,62669 & 0,4988 \\
\hline GOLD - CDSTURKEY & 3,79434 & 0,0260 \\
\hline CDSTURKEY - GOLD & 1,51115 & 0,2261 \\
\hline IHRITHKO - CDSTURKEY & 4,03058 & 0,0210 \\
\hline CDSTURKEY - IHRITHKO & 2,58245 & 0,0831 \\
\hline ISKKO - CDSTURKEY & 0,16400 & 0,8490 \\
\hline CDSTURKEY - ISKKO & 7,98492 & 0,0006 \\
\hline ITH - CDSTURKEY & 3,19644 & 0,0455 \\
\hline CDSTURKEY - ITH & 3,75826 & 0,0270 \\
\hline REELKUR - CDSTURKEY & 0,24233 & 0,7853 \\
\hline CDSTURKEY - REELKUR & 8,14710 & 0,0006 \\
\hline TCMBBOG - CDSTURKEY & 6,79168 & 0,0018 \\
\hline CDSTURKEY - TCMBBOG & 1,08209 & 0,3432 \\
\hline TUIKTGE - CDSTURKEY & 0,22935 & 0,7955 \\
\hline CDSTURKEY - TUIKTGE & 5,04735 & 0,0083 \\
\hline
\end{tabular}

\section{Sonuç ve Değerlendirme}

Regresyon analizi sonuçlarına göre; $A B D$ Dolar kurundaki ve EMBI+ Türkiye Endeksindeki aylık değișimler Türkiye 5 Vadeli ABD Doları Tahvil CDS priminin aylık değișimleri üzerinde etkili- 
dir. VAR analizi bulguları ise altın fiyatı ve Borsa İstanbul Getiri Endeksindeki değișimlerin etkili olduğunu göstermektedir.

Granger nedensellik testinin A. S. Kunt, O. Taș (2008) sonuçları ile uyumlu olduğu görülmüștür. Granger nedensellik testi sonuçlarına göre; Bankacılık Sektörü Yurtiçi Kredi Hacmi, Bloomberg Tüketici Güven Endeksi, İmalat Sanayi Kapasite Kullanım Oranı, Reel Kur ve TUIK Tüketici Güven Endeksine doğru ișleyen tek yönlü nedensellik saptanmıștır. Ayrıca Türkiye 5 Vadeli ABD Doları Tahvil CDS priminin aylık değișimler, Altın fiyatları ve Borsa İstanbul getiri endeksinin tek yönlü Granger nedenidir.

2008 yılı ve öncesindeki çalıșmalarda makroekonomik ve içsel faktörlerle etkileșim bulunurken, küresel krizle birlikte uluslararası sermaye hareketlerinin ve yurtdıșı kaynaklı hareketlerin Türk tahvillerinin CDS primleri üzerinde etkili olduğu düșünülmektedir. 2008 yılında bașlayan küresel krizin etkisi halen devam etmektedir. Kriz sonucunda piyasalarda artan likidite, finansal piyasaların yurtiçinden çok yurtdıșı piyasaları izlemesi, etkilenmesi ve yatırımcıların özellikle Avrupa Merkez Bankası ile Amerikan Merkez Bankası'nın politikaları hakkındaki bilgi ve beklentilere yönelmesi sonucunda içsel faktörlerin Türkiye 5 Vadeli ABD Doları Tahvil CDS priminin aylık değișimleri üzerindeki etkisinin azaldığı görülmektedir.

Bu çalıșma küresel kriz döneminde Türk tahvillerinin CDS primlerini etkileyen faktörlerin analizini içermektedir ve analizlerin kapsamı dar tutulmuștur. Uzun dönemde, yani Türk tahvillerinin CDS primlerinin uluslararası piyasalarda yaygın olarak izlendiği 2003 tarihinden bașlayacak çalıșma sonuçlarının ortaya konması yararlı olacaktır. Bu eksikliklere rağmen bu araștırmanın yapılacak diğer çalıșmalara ıșık tutacağı düșünülmektedir. 


\section{KAYNAKLAR}

Black, F., \& Scholes, M. 1973. The pricing of options and corporate liabilities. Journal of political economy, 81(3), 637-654.

Chan-Lau, J. A. 2003. Anticipating Credit Events Using Credit Default Swaps, with an Application to Sovereign Debt Crises. IMF Working Paper WP/03/106 May.

Choudhry, M. 2006. The Credit Default Swap Basis. New York, Bloomberg Press,

Dickey, D.A. ve Fuller, W.A. 1979. Distribution of the estimators for autoregressive time series with a unit root. Journal of the American Statistical Association. 74.

Duffie, D. 1999. Credit swap valuation. Financial Analyst Journal. 55, Jan - Feb: 73-87.

Ersan, İhsan ve Günay, S. 2009. Kredi Riski Göstergesi Olarak Kredi Temerrüt Swapları (CDSs) ve Kapatma Davasının Türkiye Riski Üzerine Etkisine Dair Bir Uygulama. Bankacılar Dergisi. 71, 3-22.

Gruber, M.J., Angrawal, D. ve Mann, C. 2001. Explaining the rate spread on corporate bonds. Journal of Finance. 56(1), $247-277$.

Gümrah, Ü. 2009. Kredi Türevleri ve Gelișmekte Olan Ülkelerde Kredi Temerrüt Swapları Üzerine Bir Araștırma. Doktora Tezi, İstanbul Üniversitesi Sosyal Bilimler Enstitüsü.

Hancı, G. 2014. Kredi Temerrüt Takasları Ve BIST-100 Arasındaki Ilișkinin İncelenmesi. http://www.iku.edu.tr/upp/8562/files/G\%C3\%B6rkem-Hanc\% C4\%B 1 (1).pdf. Erișim tarihi: 17.02.2017

Hull, J. ve White A. 2000. Valuing credit default swaps I: No counterparty default risk. Journal of Derivatives. 8, 29-40.

Hull, J., ve White A. 2001. Valuing credit default swaps II: Modeling default correlations. Journal of Derivatives. 8, 12-22.

Jarrow, R. A., \& Turnbull, S. M. 1995. Pricing derivatives on financial securities subject to credit risk. The journal of finance, 50(1), 53-85.

Karabıyık, L., Anbar, A. 2008. Kredi Tememrrüt Swapları ve Kredi Temerrüt Swaplarının Fiyatlandırılması. The Journal of Account and Finance. 31.

Kargı, B. 2014. Credit Default Swap (CDS9 Spreads: The Analysis of Time Series For The Interaction With The Interest Rates and The Growth in Turkish Economy. Montenegrin Journal of economics. 10(1), 59-66 
Kunt, A.S. ve O. Taș. 2008. Kredi temerrüt swapları ve Türkiye'nin CDS priminin tahmin edilmesine önelik bir uygulama. İüdergisi/b sosyal bilimler, 5(1), 78-89.

Koy, A. 2014 Kredi Temerrüt Swapları ve Tahvil Primleri Üzerine Ampirik Bir Çalișma. International Review of Economics And Management. 2(2), 63-79.

Litterman, R. B., \& Iben, T. 1991. Corporate bond valuation and the term structure of credit spreads. The journal of portfolio management, 17(3), 52-64.

Merton, R. C. 1974. On the pricing of corporate debt: The risk structure of interest rates. The Journal of finance, 29(2), 449-470.

Ming, H.G. 1998. The determinants of emerging market bond spread: Do economic Fundamentals matter. The World Bank Policy Research Working Paper 1899.

Pollege, S. And Peter N. Posch. 2013. Managing and trading sovereign risk using credit derivatives and government markets. The Journal of Risk Finance, Vol. 14 Issue: $5,453-467$.

Skinner, F. S., \& Townend, T. G. 2002. An empirical analysis of credit default swaps. International Review of Financial Analysis, 11(3), 297-309.

Zhang, G., J. Yau and H. G. Fung. 2010. Do credit default swaps predict currency values? Applied Financial Economics. 20, 439-458. 
